\title{
Valor nutritivo do bagaço de cana-de-açúcar amonizado com quatro doses de uréia
}

\author{
Gleidson Giordano Pinto de Carvalho(1), Aureliano José Vieira Pires(1), Cristina Mattos Veloso(1), \\ Alberti Ferreira Magalhães ${ }^{(2)}$, Mario Alberto Lopes Freire ${ }^{(3)}$, Fabiano Ferreira da Silva ${ }^{(1)}$, \\ Robério Rodrigues Silva ${ }^{(4)}$ e Bruna Mara Aparecida de Carvalho(5)
}

\begin{abstract}
(1)Universidade Estadual do Sudoeste da Bahia (Uesb), Dep. de Tecnologia Rural e Animal, Av. Palmeiras, no 491, Morumbi, CEP $45700-000$ Itapetinga, BA. E-mail: gleidsongiordano@yahoo.com.br, aureliano@uesb.br, cmveloso@uesb.br, ffsilva@uesb.br (2)Escola Média de Agropecuária da Ceplac de Itapetinga, Rod. Itapetinga-Itororó, Km 2, CEP 45700-000 Itapetinga, BA. E-mail: alberti@hnnet.com.br (3)Uesb, Praça Primavera, no 40, Bairro Primavera, CEP 45700-000 Itapetinga, BA. E-mail: freire@uesb.br (4)Uesb, Dep. de Estudos Básicos e Instrumentais. E-mail: rrsilva@uesb.br ${ }^{(5)}$ Uesb, Curso de Engenharia de Alimentos. E-mail: brunamara83@hotmail.com
\end{abstract}

Resumo - O objetivo deste trabalho foi avaliar a composição químico-bromatológica e a digestibilidade in vitro do bagaço de cana-de-açúcar, submetido à amonização com uréia. Os tratamentos constaram de quatro doses de uréia, adicionadas ao bagaço de cana-de-açúcar, e adição de 1,2\% de soja como fonte de urease. O delineamento experimental utilizado foi o inteiramente casualizado. O bagaço foi armazenado em silos de PVC com capacidade para 5,3 L, que foram abertos depois de 110 dias de amonização. Com a adição das doses de uréia ao bagaço, houve aumento linear nos teores de proteína bruta. Os teores de fibra em detergente neutro, fibra em detergente ácido, hemicelulose, celulose, lignina e carboidratos totais diminuíram, enquanto os teores de nitrogênio insolúvel em detergente ácido, nitrogênio insolúvel em detergente neutro, carboidratos não fibrosos, nitrogênio amoniacal e pH aumentaram, significativamente, com a adição de uréia. Nas doses avaliadas, a uréia adicionada ao bagaço promove aumento no conteúdo dos compostos nitrogenados, diminuição dos componentes fibrosos e aumenta a digestibilidade in vitro da matéria seca. Estimada pela equação de regressão, a adição de 2,62\% de uréia ao bagaço de cana fornece o teor mínimo de proteína bruta para o bom funcionamento do rúmen.

Termos para indexação: Saccharum oficinarum, amonização, digestibilidade in vitro, resíduo agroindustrial.

\section{Nutritive value of sugarcane bagasse ammoniated with four urea doses}

\begin{abstract}
The objective this experiment was to evaluate chemical-bromatologic composition and in vitro dry matter digestibility of sugarcane bagasse submitted to ammonization with urea. The treatments were four urea dose added to the sugarcane bagasse and addition of 1.2\% (DM basis) of soybean as urease source. The experimental design utilized was a completely randomized. The bagasse was stored in PVC silos with $5.3 \mathrm{~L}$ capacity, which were opened after 110 days of ammonization. With the urea dose addition to the bagasse, crude protein levels increased linearly. The neutral detergent fiber, acid detergent fiber, hemicelluloses, cellulose, lignin and total carbohydrates levels decreased, while the acid detergent insoluble nitrogen, neutral detergent insoluble nitrogen, nonfibrous carbohydrates, ammonia nitrogen levels and $\mathrm{pH}$ increased significantly with urea addition. At evaluated dose, the urea added to bagasse provides increase in nitrogen compounds content, decrease of fiber compounds, and increases the in vitro dry matter digestibility. Estimated by regression equation, the addition of $2.62 \%$ urea to sugarcane bagasse provides the minimum crude protein level to good functioning of the rumen.
\end{abstract}

Index terms: Saccharum oficinarum, ammoniation, in vitro digestibility, agri-industrial residue.

\section{Introdução}

O Brasil apresenta excelentes condições para a exploração de bovinos, caprinos e ovinos em pastagens, porém, em determinadas regiões, a dificuldade de se produzir alimentos volumosos, em épocas secas, tem sido a principal limitação imposta a muitos produtores. Esta época de escassez de alimento coincide com a oferta abundante de subprodutos e resíduos oriundos do processamento da cana-de-açúcar. Assim, o bagaço da cana pode ser uma alternativa para os problemas da falta de alimentos volumosos para os ruminantes, em determinadas regiões (Sarmento et al., 1999), pois apresenta potencial para 
uso na alimentação desses animais, principalmente nas regiões pecuárias, onde o período de safra da cana coincide com a falta de alimentos, como ocorre no Nordeste brasileiro.

O bagaço é resultante da extração do caldo de canade-açúcar e é caracterizado como um alimento com altos teores de parede celular, baixa densidade energética e pobre em proteína e minerais, constituindo um volumoso de baixo valor nutritivo e de baixo potencial de uso na alimentação animal (Pires et al., 2004). No entanto, seu uso será eficiente, se o valor nutritivo for melhorado pelo tratamento químico ou físico (Sarmento et al., 2001).

A fim de melhorar o valor nutritivo do bagaço de cana, para utilização na alimentação dos animais, vários trabalhos têm sido conduzidos (Cândido et al., 1999; Sarmento et al., 1999, 2001; Gesualdi et al., 2001; Torres et al., 2003). Diversos autores (Pires et al., 1999; Pires, 2000; Souza et al., 2002) têm indicado a amonização, ou seja, o tratamento químico por meio de álcalis, como alternativa viável na melhoria da qualidade desses alimentos.

O valor nutritivo de diferentes volumosos pode ser melhorado, com a utilização de tratamentos químicos (Cândido et al., 1999; Pires, 2000; Andrade et al., 2001; Reis et al., 2001), dentre os quais, a amonização de volumosos, com amônia anidra ou uréia, é a mais empregada (Souza et al., 2002).

O tratamento químico eleva os conteúdos de nitrogênio (N) e, assim, aumenta a disponibilidade para os microrganismos ruminais (Souza et al., 2001). Rosa et al. (2000) relataram que, como o material a ser amonizado, normalmente, possui baixo teor de $\mathrm{N}$, o que limita o desenvolvimento dos microrganismos, o aumento no teor desse elemento, depois da amonização, permite a atuação mais eficaz das bactérias ruminais sobre o substrato, em razão do aumento do teor de proteína bruta sintetizada, a partir da adição de $\mathrm{N}$ não protéico.

Outro efeito marcante da amonização é que a amônia provoca alterações benéficas na fração fibrosa dos volumosos, sendo, geralmente, mais expressivo sobre a fração fibra em detergente neutro, em conseqüência da solubilização parcial da hemicelulose do material amonizado (Rosa et al., 1998; Pires, 2000).

Segundo Santos et al. (2001), o custo, a disponibilidade e o emprego são as principais razões pelas quais se justifica a utilização de uréia como fonte de amônia.
Os objetivos do experimento foram avaliar a composição químico-bromatológica e a digestibilidade in vitro da matéria seca do bagaço de cana-de-açúcar, amonizado com doses crescentes de uréia.

\section{Material e Métodos}

O trabalho foi desenvolvido no Laboratório Experimental de Bovinos e no Laboratório de Forragicultura e Pastagem, da Universidade Estadual do Sudoeste da Bahia, no Campus de Itapetinga, BA, de outubro de 2003 a maio de 2004.

Foram utilizadas quatro doses de adição de uréia, 0, 2,5, 5,0 e 7,5\%, para o tratamento do bagaço de canade-açúcar, com cinco repetições por tratamento. Utilizou-se grão de soja moído como fonte de urease, adicionada, a cada tratamento, na proporção de 1,2\%. As adições de uréia e soja foram feitas com base nos conteúdos de matéria seca (MS).

O bagaço de cana-de-açúcar utilizado foi adquirido em usinas produtoras de cachaça, localizadas no $\mathrm{Mu}$ nicípio de Macarani, BA. Antes da adição de uréia ao bagaço, coletou-se uma amostra do bagaço, para avaliação de sua composição químico-bromatológica (Tabela 1).

A uréia correspondente a cada dose de inclusão e os grãos de soja moídos foram misturados ao bagaço e, em seguida, procedeu-se à homogeneização. $\mathrm{O}$ material foi armazenado em silos experimentais de PVC, com capacidade para 5,3 L, que foram vedados com lona de plástico, nas duas extremidades, com auxílio de arame liso galvanizado e fita de plástico, sendo posteriormente armazenados em galpão coberto.

Ao final do período de 110 dias de amonização, os silos foram abertos e aerados por uma hora, para permitir a volatilização do excesso de amônia. Depois des-

Tabela 1. Composição químico-bromatológica do bagaço de cana-de-açúcar, em porcentagem de matéria seca.

\begin{tabular}{lc}
\hline Componente & Composição (\%) \\
\hline Matéria seca & 40,11 \\
Proteína bruta & 2,32 \\
Fibra em detergente neutro & 59,02 \\
Fibra em detergente ácido & 38,34 \\
Hemicelulose & 20,68 \\
Celulose & 30,30 \\
Lignina & 7,34 \\
Extrato etéreo & 0,07 \\
Cinzas & 1,22 \\
Nitrogênio insolúvel em detergente neutro & 0,07 \\
Nitrogênio insolúvel em detergente ácido & 0,08 \\
Cinza insolúvel de detergente neutro & 0,65 \\
Cinza insolúvel em detergente ácido & 1,45
\end{tabular}


sa etapa, foram colhidas amostras, referentes a cada unidade experimental, as quais foram colocadas em sacos de plástico e, em seguida, armazenadas em congelador para posteriores análises. Quinze dias depois da abertura dos silos e da colheita de amostras, procedeuse à pré-secagem do material em estufa, a $55^{\circ} \mathrm{C}$, por 72 horas e, em seguida, à moagem em moinho Wiley, utilizando-se peneira de $1 \mathrm{~mm}$. Depois da moagem, as amostras foram colocadas em embalagens de plástico, identificadas e armazenadas em local fresco, até o momento de serem submetidas às análises químicobromatológicas.

As análises de proteína bruta (PB), fibra em detergente neutro (FDN), fibra em detergente ácido (FDA), celulose, lignina, hemicelulose, nitrogênio insolúvel em detergente neutro (NIDN), nitrogênio insolúvel em detergente ácido (NIDA) e digestibilidade in vitro da matéria seca (DIVMS) foram determinadas, de acordo com os procedimentos descritos em Silva \& Queiroz (2002). A porcentagem de carboidratos não fibrosos (CNF) e totais (CT) foram obtidas pelas equações:

$\mathrm{CNF}=\left(100-\% \mathrm{FDN}_{\mathrm{cp}}-\% \mathrm{~PB}-\% \mathrm{EE}-\%\right.$ cinzas $), \mathrm{e}$ $\mathrm{CT}=100-(\% \mathrm{~PB}+\% \mathrm{EE}+\%$ cinzas $)$,

em que $\mathrm{FDN}_{\mathrm{cp}}$ é a fibra em detergente neutro, corrigida para cinzas e proteína bruta; e EE é o teor de extrato etéreo do material (Sniffen et al., 1992), obtido pelo método Goldfish de extração de gordura. Parte do material (50 g) foi triturado com 200 mL de água destilada, em liquidificador, e filtrado em gaze para extração do suco, que foi utilizado, imediatamente, para análise de nitrogênio amoniacal $\left(\mathrm{N}-\mathrm{NH}_{3}\right)$ e $\mathrm{pH}$. O teor de $\mathrm{N}-\mathrm{NH}_{3}$, como porcentagem do $\mathrm{N}$ total, foi dosado imediatamente após a extração do suco, utilizando-se óxido de magnésio e cloreto de cálcio (Cunniff, 1995).

O delineamento experimental foi o inteiramente casualizado, e os resultados foram interpretados estatisticamente, por meio de análise de variância e de regressão, utilizando-se o programa SAEG - Sistema de Análises Estatísticas e Genéticas (Universidade Federal de Viçosa, 2000). A escolha dos modelos, em cada variável estudada, baseou-se no coeficiente de determinação fornecido pela análise, tendo sido adotado o nível de $1 \%$ de probabilidade.

\section{Resultados e Discussão}

Houve aumento linear no teor de PB, com a inclusão das doses de uréia ao bagaço de cana (Tabela 2). Esse aumento pode ser explicado pela adição de $\mathrm{N}$ não protéico (NNP) em doses crescentes e, portanto, na determinação do $\mathrm{N}$ total esses valores são computados como PB. De acordo com Souza et al. (2002), o N é retido por meio de uma reação da amônia com água, contida nos materiais, ou uma reação de amonólise entre a amônia e um éster, produzindo amida. Os resultados deste trabalho concordam com os obtidos por Cândido et al. (1999), que avaliaram a composição do bagaço de cana submetido a doses de 0, 2, 6 e 8\% de uréia, em presença ou não de uma fonte de urease. Aumento nos teores de PB pela amonização com uréia, tem sido observado por vários autores como Pires (2000) e Reis et al. (2001). Contudo, Souza et al. (2001) relataram que a magnitude de aumento no teor dessa fração pode sofrer grande variação, atribuída, entretanto, às diferentes condições de tratamento, como doses de amônia aplicadas, temperatura ambiente, teor de umidade, período de amonização e qualidade do material tratado.

Ferreira et al. (1990) aplicaram três doses de amônia anidra (0, 2 e 4\% na MS), no tratamento da palha de arroz, e observaram valores de 7,61, 11,24 e 12,51\% de $\mathrm{PB}$, respectivamente. No presente trabalho, o tratamento com a maior dose de uréia (7,5\% na base da MS) apresentou $12,98 \%$ de $\mathrm{PB}$, o que se aproxima do teor de $12,51 \%$, observado pelos autores no nível de $4 \%$ de $\mathrm{NH}_{3}$.

Embora as doses de uréia tenham causado efeito positivo sobre os conteúdos de $\mathrm{PB}$, isto não significa que seja pertinente adicionar altas doses de uréia (NNP), pois isto excede a necessidade dos ruminantes. O nível mínimo de PB que favorece o bom funcionamento do rúmen (7,0\% de PB) foi obtido com a adição de 2,62\% de uréia, para o valor calculado a partir da equação de regressão. $\mathrm{O}$ teor de $\mathrm{PB}$, obtido para esse nível de adição de uréia, certamente seria suficiente para manter uma atividade microbiana ativa (Santos et al., 2001), entretanto, níveis mais elevados, como os obtidos nos

Tabela 2. Teores (\%) estimados de proteína bruta (PB), fibra em detergente neutro (FDN), fibra em detergente ácido (FDA), hemicelulose (HEM), celulose e lignina do bagaço de canade-açúcar, amonizado com diferentes doses de uréia (\%MS).

\begin{tabular}{lrrrrlll}
\hline Variável & \multicolumn{4}{c}{ Uréia (\%MS) } & Equação de regressão & $\mathrm{R}^{2}$ & $\begin{array}{c}\mathrm{CV} \\
(\%)\end{array}$ \\
\cline { 2 - 5 } & 0,0 & \multicolumn{1}{c}{2,5} & 5,0 & \multicolumn{1}{c}{7,5} & & & \\
\hline PB & 3,78 & 6,85 & 9,91 & 12,98 & $\hat{\mathrm{Y}}=3,7816+1,2262 \mathrm{X}$ & 0,99 & 1,80 \\
FDN & 78,07 & 71,25 & 64,42 & 57,61 & $\hat{\mathrm{Y}}=78,0708-2,7285 \mathrm{X}$ & 0,97 & 1,34 \\
FDA & 49,04 & 44,37 & 39,61 & 34,90 & $\hat{\mathrm{Y}}=49,0414-1,8858 \mathrm{X}$ & 0,95 & 1,44 \\
HEM & 29,03 & 26,92 & 24,81 & 22,70 & $\hat{\mathrm{Y}}=29,0330-0,8448 \mathrm{X}$ & 0,98 & 3,71 \\
Celulose & 39,27 & 35,97 & 32,67 & 29,37 & $\hat{\mathrm{Y}}=39,2672-1,3191 \mathrm{X}$ & 0,95 & 1,69 \\
Lignina & 9,67 & 8,32 & 6,98 & 5,63 & $\hat{\mathrm{Y}}=9,6722-0,5391 \mathrm{X}$ & 0,95 & 6,50 \\
\hline
\end{tabular}


tratamentos 5,0 e 7,5\% de uréia, poderiam contribuir para o aumento da população de microrganismos no rúmen e aumentar, conseqüentemente, a eficiência de aproveitamento dos alimentos.

Quanto aos teores de FDN do bagaço, observou-se uma redução linear com o aumento das doses de uréia. Os teores de FDN encontrados na MS do bagaço foram 78,1, 71,3, 64,4 e 57,6\%, para as respectivas doses de $0,2,5,5,0$ e 7,5\% de uréia, o que corresponde à redução de cerca de 5,19, 18,85 e 24,87\% no conteúdo de FDN, dos bagaços tratados com 2,5, 5,0 e 7,5\% de uréia, respectivamente, em relação ao bagaço não tratado.

Redução nos teores de FDN de materiais amonizados foi observada em vários trabalhos, especialmente com subprodutos agrícolas e fenos, independentemente do nível de amônia e dos métodos usados no tratamento desses materiais (Reis et al., 1990; Neiva et al., 1998; Reis et al., 2003). Segundo Van Soest (1994), a diminuição da FDN em materiais submetidos à amonização é atribuída à solubilização da hemicelulose. Paiva et al. (1995) afirmaram que, além da solubilização da hemicelulose, pode ocorrer solubilização da lignina.

Reis et al. (1990) também registraram decréscimo nos teores de FDN, de $81 \%$ para $70,5 \%$, no feno de Brachiaria decumbens não tratado e tratado com $\mathrm{NH}_{3}$ (3\% da MS), o que corresponde a uma redução de $12,96 \%$. Praticamente em todos os trabalhos realizados e disponíveis, a amonização promoveu redução do teor de FDN. As constatações de Van Soest (1994) e Paiva et al. (1995) de que esse fato se deve à solubilização da hemicelulose corroboram os resultados obtidos.

A amonização do bagaço diminuiu os teores de hemicelulose, nas doses crescentes de uréia. Sarmento et al. (1999) aplicaram cinco doses de uréia (0, 2,5, 5,0, 7,5 e $10 \%$, na base da MS) no bagaço de cana com $55 \%$ de MS e, semelhantemente a este estudo, observaram redução no teor de hemicelulose. Neste trabalho, a redução observada no tratamento com maior dose de uréia $(7,5 \%)$, em relação ao tratamento $0 \%$, foi de $21,81 \%$, o que é equivalente à redução observada de $21,33 \%$, entre as doses 0 e $10 \%$, constatada por Sarmento et al. (1999). Resultados semelhantes de redução na fração hemicelulose foram encontrados por Ferreira et al. (1990), Reis et al. (1990), Souza \& Santos (2002) e Reis et al. (2003).

Ao trabalhar com amonização de feno de Brachiaria decumbens Stapf (3\% de $\mathrm{NH}_{3}$ na MS), Pereira et al. (1993) verificaram diminuição no conteúdo de hemicelulose, de 31,2\% para 26,5\%. Essa redução de aproximadamente $15,06 \%$, observada por esses autores, é inferior aos $21,81 \%$ obtidos nesta pesquisa.

Os valores de FDA verificados foram 49,0, 44,4, 39,6 e $34,9 \%$, respectivamente, para as doses de uréia $0,2,5$, 5,0 e $7,5 \%$. Trabalhos têm mostrado aumentos, reduções ou nenhuma alteração nos teores de FDA, celulose e lignina, promovidos pela amonização (Fadel et al., 2003). Embora os resultados da amonização sobre os teores dessas três frações não sejam consistentes (Rosa et al., 2000), no experimento realizado por Reis et al. (2003), no qual foi avaliada a amonização do feno de coast-cross, os autores relataram que os tratamentos (6\% de uréia na MS e 3,5\% de $\mathrm{NH}_{3}$ ) não afetaram os teores de FDA, celulose e lignina. Da mesma forma, Reis et al. (1995) amonizaram Brachiaria brizantha e não encontraram resultados significativos. Por sua vez, os valores de lignina da Brachiaria decumbens diminuíram, em conseqüência da aplicação de uréia, não tendo sido observadas alterações nos teores de celulose com a amonização (Rosa et al., 1998). Ao aplicar 2, 4 e $6 \%$ de uréia, e 20, 30 e $40 \%$ de água, em feno de Brachiaria brizantha cv. Marandu, Rosa et al. (2000) observaram que os tratamentos com $40 \%$ de água e 4 e $6 \%$ de uréia permitiram maior redução dos teores de FDA.

Fernandes et al. (2002) amonizaram feno de Brachiaria decumbens com 5\% de uréia (\%MS) e observaram redução no teor de lignina. De forma similar, Rosa et al. (1998) observaram diminuição de 24,6\% no conteúdo de lignina, em resposta ao tratamento com uréia. Os resultados relatados por esses autores corroboram as observações deste trabalho, pois, com o aumento das doses de uréia adicionadas ao bagaço, os teores de lignina reduziram-se. Isto ocorreu, possivelmente, pela dissolução de parte da lignina e pelo rompimento das ligações intermoleculares do tipo éster, entre o ácido urônico da hemicelulose e da celulose, durante a amonização (Van Soest, 1994).

Os teores de celulose decresceram linearmente, com a adição das doses de uréia. Bonjardim et al. (1992), ao trabalhar com amonização de feno de coast-cross e estrela africana, não observaram diferença significativa quanto à celulose. Diferentemente dos autores citados, Souza et al. (2001) observaram diminuição dos conteúdos de celulose e lignina, com a aplicação de doses de $\mathrm{NH}_{3}$ e sulfeto de sódio em casca de café. A ineficiência da uréia em alterar os compostos da fração fibrosa foi observada e descrita por Reis et al. (2003). Segundo esses autores, o conteúdo de umidade do material (23\%) 
não foi suficiente para favorecer a hidrólise da uréia e, por isso, a amonização não foi eficaz. Os resultados observados no presente trabalho contrastam com os alcançados por esses autores, provavelmente devido ao conteúdo de umidade do bagaço de cana (60\%) e à adição de $1,2 \%$ de soja em grãos moídos, fatores que propiciaram condições favoráveis para hidrólise da uréia e liberação de amônia. Portanto, as variações no efeito sobre compostos fibrosos dos materiais amonizados, em parte, podem ser atribuídas à própria constituição química do alimento que, na maioria das vezes, não satisfaz as condições necessárias para amonização. Como a soja possui alto teor de urease, a adição de $1,2 \%$ foi suficiente para promover a quebra da uréia em amônia e, conseqüentemente, desestruturação da parede celular.

Houve aumento nos teores de NIDA (\%MS), em detrimento da inclusão das doses de uréia no bagaço (Tabela 3). De maneira semelhante, Reis et al. (2001) registraram aumento nos teores de NIDA (\%MS) de 0,31, 0,42 e $0,36 \%$, respectivamente, para os fenos não tratados, tratados com amônia anidra (3\%MS), e uréia (5,4\% MS). Da mesma forma, Reis et al. (1991) também observaram aumento nos teores de NIDA, quando procederam à aplicação de 0, 2, 4 e 6\% de amônia anidra em fenos de gramíneas de clima tropical (capim-gordura e braquiária).

Sarmento et al. (1999), ao avaliar a adição de doses de $0,2,5,5,0,7,5$ e $10 \%$ de uréia ao bagaço de cana e três períodos de aeração (2, 9 e 16 dias), também observaram aumento significativo para o NIDA. No entanto, os aumentos constatados ocorreram apenas em função das doses de uréia e não se relacionaram com os períodos de aeração.

A relação NIDA por nitrogênio total (NT) diminuiu, acentuadamente, em resposta às aplicações de uréia.

Tabela 3. Nitrogênio insolúvel em detergente ácido (NIDA), nitrogênio insolúvel em detergente neutro (NIDN), carboidratos totais (CHT) e carboidratos não fibrosos (CNF) estimados no bagaço de cana-de-açúcar, amonizado com diferentes doses de uréia (\%MS).

\begin{tabular}{|c|c|c|c|c|c|c|c|}
\hline \multirow[t]{2}{*}{ Variável } & \multicolumn{4}{|c|}{ Uréia (\%MS) } & \multirow[t]{2}{*}{ Equação de regressão } & \multirow[t]{2}{*}{$\mathrm{R}^{2}$} & \multirow{2}{*}{$\begin{array}{l}\mathrm{CV} \\
(\%)\end{array}$} \\
\hline & 0,0 & 2,5 & 5,0 & 7,5 & & & \\
\hline $\mathrm{NIDA}^{(1)}$ & 0,11 & 0,13 & 0,16 & 0,19 & $\hat{\mathrm{Y}}=0,114+0,0075684 \mathrm{X}+0,0002904 \mathrm{X}^{2}$ & 0,90 & 9,85 \\
\hline NIDA $^{(2)}$ & 17,13 & 14,03 & 10,93 & 7,83 & $\hat{Y}=17,1341-1,2403 X$ & 0,90 & 8,96 \\
\hline NIDN $^{(1)}$ & 0,14 & 0,19 & 0,24 & 0,29 & $\hat{\mathrm{Y}}=0,1445-0,0199 \mathrm{X}$ & 0,82 & 6,39 \\
\hline $\mathrm{NIDN}^{(2)}$ & 22,18 & 19,22 & 16,26 & 13,31 & $\hat{\mathrm{Y}}=22,1813-1,18359 \mathrm{X}$ & 0,61 & 9,41 \\
\hline CHT & 94,02 & 91,05 & 88,08 & 85,11 & $\hat{\mathrm{Y}}=94,0184-1,1882 \mathrm{X}$ & 0,99 & 6,72 \\
\hline $\mathrm{CNF}$ & 15,97 & 18,86 & 21,74 & 24,63 & $\hat{\mathrm{Y}}=15,9720-1,1538 \mathrm{X}$ & 0,86 & 4,51 \\
\hline
\end{tabular}

(1)Em porcentagem de matéria seca. ${ }^{(2)}$ Em porcentagem de $\mathrm{N}$ total.
Foram observados valores médios da relação NIDA/NT de 17,13, 14,03, 10,93 e 7,83, respectivamente, para os bagaços tratados com 0, 2,5, 5,0 e 7,5\% de uréia. A observação destes resultados demonstra que a adição de NNP, em forma de uréia promoveu diluição do conteúdo de NIDA, aumentando o $\mathrm{N}$ total. A importância do conhecimento da modificação no teor de NIDA é justificada pelo fato de o $\mathrm{N}$ presente, nessa forma, permanecer indisponível para o animal (Agricultural and Food Research Council, 1995). Reis et al. (2001) também observaram redução significativa da relação NIDA/NT de 47,3, 20,6 e 15,9\%, respectivamente, em fenos não tratados, tratados com amônia anidra e tratados com uréia.

O conteúdo de NIDN apresentou o mesmo comportamento do NIDA, ou seja, os teores de NIDN (\%MS) aumentaram linearmente e os de NIDN/NT diminuíram. Souza et al. (2001), ao avaliar a casca de café submetida à amonização com $\mathrm{NH}_{3}(0,2,2,3,2$ e 4,2\%) e sulfeto de sódio (0, 2,1, 3,1 e 4,1\%), observaram comportamento semelhante. Quando avaliaram a qualidade do feno de Brachiaria decumbens Stapf., submetido aos tratamentos com amônia anidra ( $3 \% \mathrm{NH}_{3}$ na MS) e uréia (5\% na MS), Fernandes et al. (2002) não observaram diferença significativa quanto aos teores de NIDN. Contudo, o valor médio de NIDN relatado por esses autores, de 0,39 (\%MS), foi superior à média observada neste trabalho, que foi de 0,22 (\%MS). Talvez isso tenha ocorrido em função de a braquiária apresentar, em sua própria constituição, conteúdo de NIDN superior ao do bagaço, já que a amonização não contribuiu para o aumento significativo dessa fração na braquiária. O decréscimo nos teores de NIDN/NT verificado é decorrente do processo de amonização e evidencia que a adição do NNP, em forma de uréia, pode aumentar a quantidade de $\mathrm{N}$ disponível para síntese de proteína microbiana, dependendo do material tratado. Como normalmente esse nitrogênio presente na fibra está complexado por ligações muito fortes, pouquíssimas quantidades são aproveitadas ou degradadas pelos microrganismos do rúmen. Assim, a redução do teor de NIDN é um indicativo de melhor valor nutritivo e de maior disponibilidade de nitrogênio para a flora microbiana.

Os CT e os CNF foram afetados pela adição de uréia; entretanto, os CT sofreram diminuição linear e os CNF, aumento. Como os teores de PB normalmente são aumentados pela adição de NNP, e os de extrato etéreo e cinzas não sofrem alterações, era de se esperar redu- 
ção no teor de CT. Por sua vez, com a redução dos componentes fibrosos em materiais amonizados (Reis et al., 1991), em especial da hemicelulose, resultando em redução da fração FDN, quanto mais acentuada for a redução dessa fração, maior será o conteúdo de CNF, uma vez que, a FDN é subtraída na obtenção dos CNF.

Com relação ao teor de $\mathrm{N}-\mathrm{NH}_{3}$, constatou-se efeito quadrático das doses de uréia (Tabela 4). O bagaço de cana-de-açúcar amonizado apresentou superioridade para o teor de $\mathrm{N}_{-} \mathrm{NH}_{3}$, em relação ao não amonizado. Essa diferença é evidente, pois ao adicionar uréia, ocorre liberação de amônia e, conseqüentemente, o N-NH 3 é aumentado. Os resultados observados para essa fração corroboram os de Neiva et al. (1998), que reportaram valores de 5,8 e 35,5\%, para silagem de milho não amonizada, e amonizada com $1,2 \%$ de $\mathrm{NH}_{3}$, respectivamente.

Houve diferença quanto aos valores de $\mathrm{pH}$ dos bagaços de cana-de-açúcar estudados (Tabela 4). A amonização elevou o pH dos bagaços, e a diferença entre o não amonizado e o com maior dose de uréia foi de 60\%. Neiva et al. (1998), entretanto, observaram aumento inferior ao constatado neste trabalho. Os autores encontraram $\mathrm{pH}$ de 4 e 8,9, respectivamente, para a silagem de milho não amonizada e amonizada com $1,2 \%$ de $\mathrm{NH}_{3}$, o que corresponde a um aumento de 55,06\%. A elevação do pH do bagaço amonizado pode ser atribuída ao fato de a amônia ser uma base com alta capacidade tamponante, evitando, portanto, que a produção de ácido provoque queda acentuada do pH. Embora o $\mathrm{pH}$ seja um indicativo de qualidade, a sua elevação em materiais amonizados não implica pior qualidade (Neiva et al., 1998), pois a amônia liberada nesse processo inibe a proliferação de microrganismos indesejáveis, como fungos e leveduras, e promove a conservação do material.

Foram observados aumentos médios significativos na DIVMS dos bagaços tratados (Tabela 4) de 13,78, 24,20 e 32,42\%, respectivamente, com a aplicação de 2,5, 5,0 e 7,5\% de uréia em relação ao bagaço não tratado.

Tabela 4. Nitrogênio amoniacal em porcentagem do nitrogênio total $\left(\mathrm{N}-\mathrm{NH}_{3}\right)$, pH e digestibilidade in vitro (DIVMS) estimados no bagaço de cana-de-açúcar, amonizado com diferentes doses de uréia (\%MS).

\begin{tabular}{lrrrrrrrr}
\hline Variável & \multicolumn{3}{c}{ Uréia (\% MS) } & & Equação de regressão & $\mathrm{R}^{2}$ & $\begin{array}{l}\mathrm{CV} \\
(\%)\end{array}$ \\
\cline { 2 - 5 } & 0,0 & 2,5 & 5,0 & 7,5 & & & \\
\hline $\mathrm{N}-\mathrm{NH} 3$ & 6,73 & 52,28 & 71,97 & 65,81 & & $\hat{\mathrm{Y}}=6,72891+23,3923 \mathrm{X}-2,06858 \mathrm{X}^{2}$ & 0,98 & 1,52 \\
$\mathrm{pH}$ & 3,66 & 5,48 & 7,31 & 9,14 & $\hat{\mathrm{Y}}=3,6638+0,7299 \mathrm{X}$ & 0,95 & 1,18 \\
DIVMS & 32,97 & 38,24 & 43,51 & 48,79 & $\hat{\mathrm{Y}}=32,9676+2,10944 \mathrm{X}$ & 0,98 & 5,23 \\
\hline
\end{tabular}

De acordo com Reis et al. (1990, 2001), as alterações na composição química da fração fibrosa, com a solubilização de parte da hemicelulose a acarretar aumento no conteúdo de carboidratos prontamente digestíveis e de $\mathrm{N}$ disponível para os microrganismos do rúmen são, provavelmente, os fatores responsáveis pelo incremento da DIVMS em materiais amonizados.

De maneira semelhante, Sarmento et al. (1999) observaram incrementos significativos na DIVMS do bagaço de cana-de-açúcar submetido à amonização. Os autores reportaram aumentos de 38,0, 47,7, 47,3 e $53,9 \%$, com a adição de $2,5,5,0,7,5$ e $10 \%$, respectivamente, de uréia, em relação ao bagaço não tratado. Por outro lado, Pires et al. (1999) observaram incrementos de apenas $13 \%$ na DIVMS da quirera de milho com alta umidade, ao adicionar doses de 0, 1, 2 e 3\% de $\mathrm{NH}_{3}$.

$\mathrm{O}$ tratamento de materiais com produtos alcalinos provoca a solubilização parcial da hemicelulose e a expansão da celulose, o que facilita o ataque de microrganismos à parede celular, com conseqüente aumento na digestibilidade do material tratado (Sarmento et al., 1999; Pires et al., 2004). Os incrementos na DIVMS de volumosos tratados com produtos alcalinos, normalmente, aumentam o consumo e desempenho animal, podendo, às vezes, apresentar resultados semelhantes em termos de desempenho, quando comparados a dietas de melhor qualidade.

\section{Conclusões}

1. A amonização com uréia proporciona melhoria no valor nutritivo do bagaço de cana-de-açúcar, comprovada pela elevação do teor de proteína bruta e pela redução do conteúdo de fibra em detergente neutro.

2. A dose mínima de adição de uréia ao bagaço de cana-de-açúcar é de 2,62\%, para o bom funcionamento e desenvolvimento dos microrganismos ruminais.

3. A amonização nas dosagens utilizadas aumenta a digestibilidade do bagaço de cana-de-açúcar, em decorrência das alterações observadas nos constituintes da parede celular.

\section{Agradecimentos}

Ao CNPq e à Fundação de Amparo a Pesquisa do Estado da Bahia, pela concessão de bolsas; à Universidade Estadual do Sudoeste da Bahia, pelo financiamento do projeto. 


\section{Referências}

AGRICULTURAL AND FOOD RESEARCH COUNCIL. Energy and protein requirements of ruminants. Farnham Royal: $C A B$ International, 1995. 59p.

ANDRADE, J.B.; FERRARI JÚNIOR, E.; BRAUN, G. Valor nutritivo da silagem de cana-de-açúcar tratada com uréia e acrescida de rolão-de-milho. Pesquisa Agropecuária Brasileira, v.36, p.11691174, 2001.

BONJARDIM, S.R.; REIS, R.A.; RODRIGUES, L.R.A. Avaliação da qualidade dos fenos de gramíneas tropicais armazenados com diferentes níveis de umidade e tratados com amônia. Revista Brasileira de Zootecnia, v.21, p.866-873, 1992.

CÂNDIDO, M.J.D.; NEIVA, J.N.M.; PIMENTEL, J.C.M.; VASCONCELOS, V.R.; SAMPAIO, E.M.; MENDES NETO, J. Avaliação do valor nutritivo do bagaço de cana-de-açúcar amonizado com uréia. Revista Brasileira de Zootecnia, v.28, p.928-935, 1999.

CUNNIFF, P. Official methods of analysis of AOAC International. $16^{\text {th }}$ ed. Arlington: AOAC International, 1995. v.1.

FADEL, R.; ROSA, B.; OLIVEIRA, I.P.; OLIVEIRA, J.D.S. Avaliação de diferentes proporções de água e de uréia sobre a composição bromatológica de palha de arroz. Ciência Animal Brasileira, v.4, p.101-107, 2003.

FERNANDES, L.O.; REIS, R.A.; RODRIGUES, L.R.A.; LEDIC, I.L.; MANZAN, R.J. Qualidade do feno de Brachiaria decumbens Stapf. submetido ao tratamento com amônia anidra ou uréia. Revista Brasileira de Zootecnia, v.31, p.1325-1332, 2002.

FERREIRA, J.Q.; GARCIA, R.; QUEIROZ, A.C. Efeito dos níveis de amônia e dos períodos pós-tratamento sobre a qualidade da palha de arroz. Revista Brasileira de Zootecnia, v.19, p.39-43, 1990.

GESUALDI, A.C.L.S.; SILVA, J.F.C.; VASQUES, H.M.; ERBESDOBLER, E.A. Efeito da amonização sobre a composição, retenção de nitrogênio e a conservação do bagaço e da ponta de canade-açúcar. Revista Brasileira de Zootecnia, v.30, p.508-517, 2001.

NEIVA, J.N.M.; GARCIA, R.; VALADARES FILHO, S.C.; SILVA, F.C.; PIRES, A.J.V.; PEREIRA, O.G. Características fermentativas das silagens de milho amonizadas. Revista Brasileira de Zootecnia, v.27, p.474-480, 1998.

PAIVA, J.A.J.; GARCIA, R.; QUEIROZ, A.C. Efeito dos níveis de amônia anidra e períodos de amonização sobre os teores de compostos nitrogenados e retenção de nitrogênio na palhada de milho. Revista Brasileira de Zootecnia, v.24, p.672-682, 1995.

PEREIRA, J.R.A.; EZEQUIEL, J.M.B.; REIS, R.A.; RODRIGUES, L.R.A.; BONJARDIM, S.R. Efeitos da amonização sobre o valor nutritivo do feno de capim braquiária. Pesquisa Agropecuária Brasileira, v.28, p.1451-1455, 1993.

PIRES, A.J.V. Bagaço de cana-de-açúcar tratado com amônia anidra e, ou, sulfeto de sódio para novilhas em crescimento. 2000. 65p. Tese (Doutorado) - Universidade Federal de Viçosa, Viçosa.

PIRES, A.J.V.; GARCIA, R.; CECON, P.R.; NEIVA, J.N.M.; SARMENTO, P. Amonização da quirera de milho com alta umidade. Revista Brasileira de Zootecnia, v.28, p.1186-1193, 1999.

PIRES, A.J.V.; GARCIA, R.; VALADARES FILHO, S.C.; PEREIRA, O.G.; CECON, P.R.; SILVA, F.F.; SILVA, P.A.; ITAVO,
L.C.V. Degradabilidade do bagaço de cana-de-açúcar tratado com amônia anidra e, ou, sulfeto de sódio. Revista Brasileira de Zootecnia, v.33, p.1071-1077, 2004.

REIS, R.A.; ANDRADE, P.; RODRIGUES, L.R.A. Palha de arroz e feno de Brachiaria brizantha amonizados e suplementados com energia ou proteína na alimentação de bovinos. Revista Brasileira de Zootecnia, v.24, p.832-840, 1995.

REIS, R.A.; BERCHIELLI, T.T.; ANDRADE, P.; MOREIRA, A.L.; SILVA, E.A. Valor nutritivo do feno de capim coast-cross (Cynodon dactylon L. Pers.) submetido à amonização. ARS Veterinaria, v.19, p.143-149, 2003.

REIS, R.A.; GARCIA, R.; QUEIROZ, A.C.; SILVA, D.J.; FERREIRA, J.Q. Efeitos da amonização sobre a qualidade do feno de gramíneas tropicais. Pesquisa Agropecuária Brasileira, v.26, p.1183-1191, 1991.

REIS, R.A.; GARCIA, R.; SILVA, D.J.; QUEIROZ, A.C.; FERREIRA, J.Q. Efeitos da aplicação de amônia anidra sobre a digestibilidade do feno de capim-braquiária (Brachiaria decumbens Stapf). Revista Brasileira de Zootecnia, v.19, p.201-208, 1990.

REIS, R.A.; RODRIGUES, R.L.A.; RESENDE, K.T.; PEREIRA, J.R.A.; RUGGIERI, A.C. Avaliação de fontes de amônia para o tratamento de fenos de gramíneas tropicais. I. Constituintes da parede celular, poder tampão e atividade ureática. Revista Brasileira de Zootecnia, v.30, p.674-681, 2001.

ROSA, B.; REIS, R.A.; RESENDE, K.T.; KRONKA, S.N.; JOBIM, C.C. Valor nutritivo do feno de Brachiaria decumbens Stapf cv. Basilisk submetido a tratamento com amônia anidra ou uréia. Revista Brasileira de Zootecnia, v.27, p.815-822, 1998.

ROSA, B.; SOUZA, H.; RODRIGUES, K.F. Composição química do feno de Brachiaria brizantha cv. Marandu tratado com diferentes proporções de uréia e de água. Ciência Animal Brasileira, v.1, p.107-113, 2000.

SANTOS, G.T.; CAVALIERI, F.L.B.; MODESTO, E.C. Recentes avanços em nitrogênio não protéico na nutrição de vacas leiteiras. In: SINLEITE, 2., 2001, Lavras. Anais. Lavras: Ufla, 2001. p.199-228.

SARMENTO, P.; GARCIA, R.; PIRES, A.J.V.; NASCIMENTO, A.S. Grãos de soja como fonte de urease na amonização do bagaço de cana-de-açúcar com uréia. Scientia Agricola, v.58, p.223-227, 2001.

SARMENTO, P.; GARCIA, R.; PIRES, A.J.V.; NASCIMENTO, A.S. Tratamento do bagaço de cana-de-açúcar com uréia. Revista Brasileira de Zootecnia, v.28, p.1203-1208, 1999.

SILVA, D.J.; QUEIROZ, A.C. Análise de alimentos: métodos químicos e biológicos. Viçosa: UFV, 2002. 235p.

SNIFFEN, C.J.; O’CONNOR, J.D.; VAN SOEST, P.J.; FOX, D.G.; RUSSEL, J.B. A net carbohydrate and protein system for evaluating cattle diets: II. Carbohydrate and protein availability. Journal of Animal Science, v.70, p.3562-3577, 1992.

SOUZA, A.L.; GARCIA, R.; PEREIRA, O.G.; CECON, P.R.; PIRES, A.J.V.; LOURES, D.R.S. Valor nutritivo da casca de café tratada com amônia anidra. Revista Ceres, v.26, p.669-681, 2002.

SOUZA, A.L.; GARCIA, R.; PEREIRA, O.G.; CECON, P.R.; VALADARES FILHO, S.C.; PAULINO, M.F. Composição químico-bromatológica da casca de café tratada com amônia anidra e sulfeto de sódio. Revista Brasileira de Zootecnia, v.30, p.983991, 2001. (Suplemento, 1). 
SOUZA, O.; SANTOS, I.E. Digestibilidad in vivo, balance de nitrógeno e ingestión voluntaria en ovinos alimentados con paja de cabada tratada con urea. Archivos de Zootecnia, v.51, p.361-371, 2002.

TORRES, L.B.; FERREIRA, M.A.; VÉRAS, A.S.C.; MELO,A.A.S.; ANDRADE, D.K.B. Níveis de bagaço de cana e uréia como substituto ao farelo de soja em dietas para bovinos leiteiros em crescimento. Revista Brasileira de Zootecnia, v.32, p.760767, 2003.

UNIVERSIDADE FEDERAL DE VIÇOSA. SAEG: sistema de análises estatísticas e genéticas. Viçosa, 2000. 301p. Apostila.

VAN SOEST, P.J. Nutritional ecology of the ruminant. $2^{\text {nd }}$ ed. Ithaca: Cornell University Press, 1994. 476p.

Recebido em 10 de agosto de 2004 e aprovado em 6 de maio de 2005 